\title{
The Baltic states: building on 20 years of health reforms
}

The Baltic States are recovering from a crisis as deep as Greece's. Van Ginneken and colleagues suggest that the crisis has provided an opportunity to improve efficiency and equity, although concerns about financial sustainability and the impact on public health remain

\author{
Ewout van Ginneken senior researcher ${ }^{1}$ honorary research fellow ${ }^{2}$, Jarno Habicht WHO \\ representative $^{3}$, Liubove Murauskiene director ${ }^{4}$, Daiga Behmane member of the board ${ }^{5}$, Philipa \\ Mladovsky research fellow ${ }^{26}$
}

\begin{abstract}
${ }^{1}$ Department of Health Care Management, Berlin University of Technology, Strasse des 17 Juni 135, Berlin 10623, Germany; ${ }^{2}$ European Observatory on Health Systems and Policies, rue de l'Autonomie 4, B-1070 Brussels, Belgium; ${ }^{3}$ WHO Country Office in Republic of Moldova, World Health Organization, 29 Sfatul Tarii Street, MD2029 Chisinau, Republic of Moldova; ${ }^{4}$ MTVC (Training, Research and Development Center), Antakalnio 22B, Vilnius LT-10305, Lithuania; ${ }^{5}$ Latvian Association of Health Economics, 85-7 Brivibas Street, Riga, LV1001, Latvia; ${ }^{6}$ LSE Health, London School of Economics and Political Science, London WC2A 2AE, UK
\end{abstract}

The Baltic states Estonia, Latvia, and Lithuania regained independence in the early 1990s in the aftermath of the dissolution of the Soviet Union. Since then, they have had a rocky path to health reform. The reforms have been aimed at making a clear break with the Soviet-style Semashko model, which was characterised by central planning and universal access but which suffered from inefficiency, hospital overcapacity, and poor healthcare. ${ }^{1}$ Early reforms, similar across all the Baltic states, focused on improving quality, efficiency, and geographical and timely access to healthcare. Yet differences in size, language, politics, economy, and culture (fig $1 \Downarrow$ ) perhaps explain variations in the implementation of the reforms. In recent times, a difficult economic climate has required some tough austerity measures to balance public budgets. We discuss these reforms, the impact of the global financial crisis, and some challenges for the future.

\section{Decentralising and recentralising financing arrangements}

After independence, all three Baltic states adopted social health insurance systems. For these countries, with their deep rooted distrust of government, a system in which organisational and health financing arrangements lay largely outside the state sector was an attractive prospect. ${ }^{2}$ Additionally, by introducing a purchaser-provider split, they hoped to increase transparency and efficiency. Finally, in a fragile economic environment, earmarked payroll tax was seen as a more stable funding source than general tax. However, in all three states, the decentralisation of the financing system resulted in inefficient and fragmented allocation of resources and was followed by a gradual recentralisation. As a result, by 2012, the three systems had reintroduced, to varying degrees, some of the features of the pre-reform system, such as centralised planning and increased reliance on tax funding (box 1). Their different solutions for resource generation and governance arrangements have affected the states' ability to respond to economic crises.

\section{Prioritising family medicine}

Primary care has been made a reform priority. Under the Soviet system, primary care had been provided in polyclinics and health centres owned by the municipalities. Pay was low, coordination of care was poor and fragmented, and primary care doctors and nurses were unmotivated, often leading to poor care. To remedy this, the Baltic states introduced family medicine as a new specialty (Estonia in 1991; Lithuania, 1992; and Latvia, 1993). ${ }^{48}$ These new family doctors were to act as gatekeepers and coordinators in healthcare. International agencies such as the World Health Organization and the World Bank played key roles (through advice and loans) in the adoption of the family doctor model, often modelled on the UK and Dutch systems. ${ }^{1}$ Yet training doctors and changing the attitude of the population need time. Even today, public acceptance of the family doctor is low in Latvia, and patients can still access many specialists directly (for example, for psychiatric diseases, tuberculosis, sexually transmitted diseases, diabetes, cancer, and 


\section{Box 1 Health financing reforms in the Baltic states}

Initially, both Estonia and Latvia implemented decentralised "multipayer" social insurance systems. In 1991, Estonia introduced 22 sickness funds that each collected contributions; there was no central pooling and no transfer of resources between regions. This led to widening regional inequalities and the decision to gradually recentralise health financing. In the mid-1990s, Estonia introduced central collecting and pooling through a central fund, which allocated the money to regional funds. In the early 2000 s the Estonian Health Insurance Fund (EHIF) was introduced as a single autonomous public body responsible for pooling and purchasing. The fund was governed by a supervisory board with representatives of the state, employers, and insured individuals. The regional sickness funds were reorganised into four regional EHIF branches. $^{34}$

Latvia introduced 35 regional sickness funds in 1993, financed from central revenue because attempts to introduce contributions failed. However, the many funds proved inefficient and led to large regional inequalities in terms of access, provision, and quality. A single fund, the State Compulsory Health Insurance Agency, was introduced in $1997,{ }^{5}$ at first allocating funds to eight regional branches, then in 2005 becoming a single payer/purchaser with five regional branches, exclusively funded from general taxes. In 2011 it was reformed into the National Health Service. ${ }^{6}$

In 1991 Lithuania changed from a fully tax funded system to a system based partly on contributions but, unlike Estonia and Latvia, did not introduce multiple health insurance funds ${ }^{7}$ Instead, an autonomous National Health Insurance Fund (NHIF) was established. Since 2003 it has had five regional branches, funded from contributions and an increasing tax share. There was a recentralisation of responsibility when the NHIF became subordinate to the Ministry of Health in 2002 (previously it had been accountable to the state government and an independent steering board).

The different Baltic systems, as they stand in 2012, illustrate that the difference between tax funded NHS-type systems and contribution funded social insurance systems has become blurred and less relevant to interpreting health system differences.

emergencies). In Lithuania, especially in the cities, many patients use family doctors only to get a referral to a specialist. In Estonia, patients and specialists have slowly come to understand the role of the family doctor and the reform is seen as a success. ${ }^{9}$

As the Soviet system had emphasised hospital care, building up family medicine based primary care needed to be linked with a reduction in hospitals and hospital beds. However, reforms in the early 1990s decentralised responsibility and ownership of health service provision and providers to local government, and the municipalities protected local providers and showed limited interest in restructuring. Therefore, as with financing, planning was recentralised to enable reform of the hospital infrastructure while meeting population needs. Estonia (in 2000), Latvia (2002), and Lithuania (2003) all rolled out programmes to restructure their hospital sectors, which have led to further declining numbers of beds per 1000 population. However, the pace of implementation varied; Latvia, for example, did not implement the plan in earnest until the economic crisis struck.

\section{Improving health status}

The reforms, together with other factors such as economic progress and lifestyle changes, have contributed to some major improvements in health status. Estonia's life expectancy dipped strongly in the early 1990s, but since then the gap in life expectancy has been slowly closing between Estonia and the EU12 (the 12 countries that joined the EU in 2004 and 2007), Germany, and the UK (fig $2 \Downarrow$ ). ${ }^{10}$ In Latvia and Lithuania, however, after initial improvements, the gap widened again as life expectancy levelled off, or even fell for several years. However, from 2007 to 2010 both countries caught up rapidly. The main causes contributing to the remaining gap are cardiovascular diseases, cancers, and (in men) external injuries and poisoning (box 2). Moreover, older people have not shared in these gains and are slipping further behind, especially in Lithuania. ${ }^{11}$ Infant mortality has shown major improvements in all three countries (fig $3 \Downarrow$ ). ${ }^{10}$ Estonia and Lithuania have outperformed the EU12 group and achieved levels comparable to those of the UK and Germany, and Latvia has caught up with the steadily improving EU12 group.

\section{"Out of pocket" payments remain high and "informal" payments persist}

All three Baltic states require patients to make substantial contributions towards the total expenditure on healthcare. "Out of pocket" payments mainly take the form of contributions towards the cost of medical drugs ("cost sharing") and direct payments for adult dental care. Other services that patients must either contribute to or pay for entirely include cosmetic surgery, complementary and alternative medicine (all three Baltic states); abortion, alcohol detoxification, health checks, and occupational health checks (Latvia and Lithuania); and some psychotherapy, psychology, trauma surgery, and orthopaedic services (Latvia). As a proportion of the total expenditure on healthcare, out of pocket payments account for $19.6 \%$ in Estonia, $25.8 \%$ in Lithuania, and $37.8 \%$ in Latvia, compared with $23.9 \%$ in the EU12, $13.0 \%$ in Germany and $10.0 \%$ in the UK in $2010 .^{10}$

"Informal" payments are unofficial payments by patients to individual and institutional providers (in kind or in cash) that are made outside official payment channels. These payments still play a considerable role in Latvia and especially in Lithuania, which has the highest number of unofficial payments and the greatest mistrust of the system. ${ }^{13}$

The high level of out of pocket and informal payments compromises equity of access and disproportionately affects lower income groups. ${ }^{14}$ It also reflects the challenge of limited public resources in the system, which was recognised even before the global financial crisis struck.

\section{Global crisis then austerity}

Although the Baltic countries were on a steep trajectory to catch up with the EU15 (the first 15 nation members of the European Union) for many indicators, the global economic crisis of 2008 pushed the vulnerable, small, and open Baltic economies into a deep recession. In 2009, the Estonian, Latvian, and Lithuanian economies contracted by $14.1 \%, 17.7 \%$, and $14.8 \%$ respectively, ${ }^{15}$ and unemployment (only $3.9 \%$ in Estonia, 5.7\% in Latvia in the final quarter of 2007) rose rapidly, peaking in January 2010 in Latvia (21.6\%) and Estonia (19.8\%) and in April 2010 in Lithuania (18.7\%). ${ }^{16}$ All three health systems were seriously affected because revenue from insurance contributions dropped dramatically (Estonia and Lithuania), as did revenue from tax (all three). ${ }^{17}$ Since then, however, unemployment rates have been falling quickly, although how the international debt crisis will affect this recovery remains unclear.

The sharp drops in revenue and the limited capacity for raising extra resources necessitated drastic cuts in health sector spending (table $\Downarrow$ ). Estonia rolled out a diverse austerity package involving some cuts in benefits and prices, increased cost sharing for certain services, extended waiting times, increased value added tax (VAT) on medications (from 5\% to $9 \%$ ), promotion of rational use of medicine, a focus on primary and outpatient care, 


\section{Box 2 Health trends in the Baltic states ${ }^{10} 12$}

Cardiovascular disease, neoplasms, and external injuries and poisoning are the three most important causes of death in the Baltic states. For cardiovascular disease and injuries and poisoning, the Baltic states are among the worst performers in Europe. Lithuania raises the most serious concerns-494.5 deaths from cardiovascular disease per 100000 population compared with the EU average of 221.8; and 113.1 deaths from injuries and poisoning per 100000 population compared with 36.5 in the EU (2010).

These comparatively high death rates are largely explained by male mortality: male life expectancy in Estonia, Latvia, and Lithuania is 70.6 , 68.6 , and 68.0 years respectively; female life expectancy is about 10 years higher, at $80.8,78.4$, and 79.0 years respectively. The corresponding EU rates are 77.0 for men and 82.2 for women (2010). The large male-female difference in the three Baltic states is related to men's particularly unhealthy lifestyles, characterised by higher levels of smoking and binge drinking. Indeed, in Estonia $36.8 \%$ of males aged $>15$ years smoke daily, as do $47.4 \%$ in Latvia and $34.2 \%$ in Lithuania (2010). The corresponding proportion in the UK (2009) is $22 \%$. Furthermore, Estonian adults drink on average 6.6 litres of spirits annually (2009), Latvians 7.7 litres, and Lithuanians 5.5 litres (2008), compared with the EU average of 2.4 litres (2009).

Poor diet also contributes to unhealthy lifestyles, although this has been changing in recent years owing to greater availability of vegetable oils and fresh fruit and vegetables.

These risk factors, combined with the psychosocial impacts of dramatic political and economic upheavals, are largely to blame for this sharp rise in Baltic mortality at the start of the 1990s (immediately after the fall of the Communist system) and again in the middle to late 1990s. Consequently, during the 1990 s life expectancy barely increased, especially among men. Whether the current financial crisis will have a similar impact is still unclear, although the initial signs are hopeful, as life expectancy has continued to increase since 2007.

and a reduction in specialised care. Salaries were not explicitly cut, but they fell because of a drop in available funding.

In Latvia, much non-emergency care (such as diagnostics, planned hospital care) was shifted to day care, and hospitals only had to accept emergency patients and could charge fees to others; prices were cut by at least $10 \%$; strict hospital budgeting (replacing a "fee for service" arrangement) was reintroduced; waiting times were extended (mostly in non-emergency care), VAT on medications was increased (from 5\% to 12\%); cost sharing was expanded; and wages for health workers were cut by a $20 \%$. Primary care was prioritised, with increased funding, and a social safety net for vulnerable groups was implemented (with World Bank support) to meet the challenges posed by the already very high out of pocket payments.

In Lithuania, the austerity package was less strong and mostly included price cuts (excluding ambulance and primary care) and relatively small cuts in benefits. Instead, the National Health Insurance Fund was strengthened by increasing the contribution rate, the state contribution (to cover economically inactive people), and the number of contributors. As in Estonia and Latvia, outpatient care was prioritised, but in contrast, cost sharing was not increased.

\section{Public health}

In public health, tough measures were implemented. In Estonia the Ministry of Social Affairs had to reduce its expenditure by $24 \%$ in 2009 compared with 2008 . The cut was partially achieved through reducing administrative costs and the public health budget, although the latter was protected to some extent by some temporary EU structural funds. In Latvia the public health budget was cut by about $89 \%$ from 2008 to 2010 and the Public Health Agency was closed in 2009. Many public health functions were distributed among other institutions and some were lost. In Lithuania seven public health institutions were merged in 2009-10 and the public health budget was cut by about $10 \%$ from 2008 to 2010 .

\section{Potential impacts of the current reforms}

Estimating the impact of these measures is difficult, although some tentative conclusions can be drawn. On the positive side, the financial crisis has provided opportunities to improve the efficiency, quality, and equity of the Baltic health systems. Examples include the intensification of existing policies to promote hospital restructuring and primary care, financial protection for vulnerable groups, and the rational use of medicines. Furthermore, all three states used the crisis to reduce the price of medical goods through reference pricing and price agreements; in Estonia and Latvia this was a continuation of "pre-crisis" policy, but in Lithuania this was a direct response to the crisis. ${ }^{18-20}$ Insurance funds in Estonia and Lithuania were prepared and could use reserves to weather the crisis. Lastly, all three states invested substantial international stimulus money from EU structural funds for 2007-13, together with some national funding in health infrastructure and public health (Estonia about $€ 146 \mathrm{~m}$, Latvia $€ 247 \mathrm{~m}$, and Lithuania $€ 240 \mathrm{~m}$ ). ${ }^{21}$

Less positively, increases in already high out of pocket payments may reduce the use of high value care, particularly among lower income individuals and older people, even when the cost to users is low. ${ }^{22-25}$ This may lead to increased spending in other areas (such as emergency care) and reduced efficiency overall. In Latvia, for example, increased charges for hospital care led to a steep increase in patients trying to seek access through the emergency units. In 2010, 26.8\% of Latvians in the first income quintile reported an unmet medical need, the highest percentage in the EU (average 5.2\%). ${ }^{26}$ Raising user charges on only low value services or implementing exemptions for vulnerable groups may enhance efficiency and equity.

Similarly, expenditure cuts in public health are worrying. The dramatic increase in new HIV cases among injecting drug users in Greece, thought to be caused partly by reduced service provision resulting from the financial crisis ${ }^{27}$ should serve as a stark warning to the Baltic states (especially Estonia, where an HIV epidemic that peaked in the early 2000s is still a major public health challenge). Fortunately, Estonia prioritised communicable diseases (such as HIV and tuberculosis), but the budget for non-communicable diseases (cardiovascular disease and cancer) was cut.

Interestingly, the relative increase in prices and the strengthened policy in Estonia has reduced alcohol consumption during the crisis. ${ }^{28}$ Yet in Spain the recession has significantly increased alcohol misuse among people attending primary care, ${ }^{29}$ so the Baltic states must stay alert as they still have high levels of alcohol consumption, which have led to a high burden of premature mortality, especially in Lithuania. ${ }^{11}$

Wage reductions in the three states are also worrying as they risk exacerbating wage imbalances in and across countries and increasing emigration of health workers, thereby possibly undermining quality and efficiency in the health system. ${ }^{30}$ Although increasing wages in pre-crisis Estonia and Lithuania have reduced the outflow of skilled professionals, ${ }^{31}{ }^{32}$ lower wages in Estonia and Latvia could motivate health workers to find employment abroad. Although official statistics in Lithuania show stable salaries among health workers, trade unions claim that salaries have been cut by as much as $20 \%$ in some cases and have planned strikes. In Estonia, salary reductions for health 
professionals were lower than in other economic sectors. But now that health service prices have been restored to their pre-crisis levels, a growing discontent among health workers is observed and strikes took place in early October 2012. Data from these countries are needed to keep monitoring the trends. A range of non-financial tools to retain workers (such as offering study leave, better holiday arrangements, flexible working hours, access to training) might counter negative effects.

\section{Conclusion}

The Baltic states are yet again at a crossroads in their 20 year quest to improve their health systems. As in all countries, including the UK, the financial crisis has provided an opportunity to enhance value in the health system (rather than focusing on areas where cuts might be made most easily). ${ }^{33}$ Although the challenges differ in detail among the three Baltic states, in general they include ensuring a stable source of funding; establishing the model of the family doctor firmly at the centre of service delivery; developing specialised care delivery models that are effective and not only hospital centred; promoting innovative payment methods resulting in the purchasing of efficient care; ensuring a workforce policy that retains and develops health professionals; and increasing the accountability of performance. The aim should be to ensure that the severe cuts in public expenditure on health will not jeopardise the reform process or the substantial gains made in the past 20 years. Although the Baltic states have returned to economic growth after enduring a crisis as deep as Greece's,${ }^{34}$ they need to start investing again in high value services such as public health. ${ }^{35}$

Contributors: EvG devised the article after discussions with $\mathrm{JH}$ and wrote the first draft, which was revised by PM. JH, DB, and LM supplied the material on Estonia, Latvia, and Lithuania and contributed to subsequent drafts. EvG and PM wrote the final draft. All have read and agreed with the final version.

Competing interests: All authors have completed the ICMJE uniform disclosure form at www.icmje.org/coi_disclosure.pdf (available on request from the corresponding author) and declare: no support from any organisation for the submitted work; no financial relationships with any organisations that might have an interest in the submitted work in the previous three years; no other relationships or activities that could appear to have influenced the submitted work.

Provenance and peer review: Commissioned; externally peer reviewed.

1 Bankauskaite V, O'Connor JS. Health policy in the Baltic countries since the beginning of the 1990s. Health Policy 2008;88:155-65.

2 Rechel B, McKee M. Health reform in central and eastern Europe and the former Sovie Union. Lancet 2009;374:1186-95.

3 Habicht T. Governing a single-payer mandatory health insurance system: the case from Estonia. In: Savedoff WD, Gottret P, eds. Governing mandatory health insurance. Learning from experience. World Bank, 2008.

4 Koppel A, Kahur K, Habicht T, Saar P, Habicht J, van Ginneken E. Estonia: health system review. Health Systems in Transition 2008;10(1):1-230.

5 Tragakes E, Brigis G, Karaskevica J, Rurane A, Stuburs A, Zusmane E, et al. Latvia: health system review. Health Systems in Transition 2008;10(2):1-253.

6 Mittenbergs U, Taube M, Misinš J, Miḳitis E, Martinsons A, Rurane A, et al. Latvia: health system review. Health Systems in Transition [forthcoming].

7 Cerniauskas G, Murauskiene L, Tragakes E. Health care systems in transition: Lithuania. WHO Regional Office for Europe on behalf of the European Observatory on Health Care Systems, 2000.

8 Atun RA, Ibragimov A, Ross G, Meimanaliev A, Hovhannasiyan S, Cibotaru E, et al. Review of experience of family medicine in Europe and Central Asia. Vol 1 (executive summary). World Bank Report No 32354-ECA. World Bank, 2005.
9 Atun RA, Menabde N, Saluvere K, Jesse M, Habicht J. Introducing a complex health innovation-primary health care reforms in Estonia (multimethods evaluation). Health Policy 2006;79:79-91.

10 WHO Regional Office for Europe. European Health for All database (HFA-DB). 2012. www.euro.who.int/hfadb.

11 Karanikolos M, Leon DA, Smith PC, McKee M. Minding the gap: changes in life expectancy in the Baltic States compared with Finland. J Epidemiol Community Health 2012 66:1043-9.

12 McKee M, Adany R, MacLehose L. Health status and trends in candidate countries. In: McKee LMM, Nolte E, eds. Health policy and European enlargement. WHO Regional Office for Europe on behalf of the European Observatory on Health Systems and Policies, 2004.

13 Cockcroft A, Andersson N, Paredes-Solís S, Caldwell D, Mitchell S, Milne D, et al. An inter-country comparison of unofficial payments: results of a health sector social audit in the Baltic States. BMC Health Serv Res 2008:8:15.

14 Habicht J, Kiivet RA, Habicht T, Kunst AE. Social inequalities in the use of health care services after 8 years of health care reforms-a comparative study of the Baltic countries. Int J Public Health 2009;54:250-9.

15 Eurostat. Real GDP growth rate. 2012. http://epp.eurostat.ec.europa.eu/tgm/table.do? tab=table\&init $=1$ \&plugin $=1$ \&language $=$ en\&pcode $=$ tec00115.

16 Eurostat. EU labour force survey. 2012. http://epp.eurostat.ec.europa.eu/portal/page/ portal/employment_unemployment_lfs/introduction.

17 Habicht J, van Ginneken E. Estonia's health system in 2010: improving performance while recovering from a financial crisis. Eurohealth 2010;16(2):19-32.

18 Garuoliene K, Alonderis T, Marcinkevicius M. Pharmaceutical policy and the effects of the economic crisis: Lithuania. Eurohealth 2011;17(1):1-4.

19 Rüütel D, Pudersell K. Pharmaceutical policy and the effects of the economic crisis: Estonia. Eurohealth 2011;17(1):5-8

20 Behmane D, Innus J. Pharmaceutical policy and the effects of the economic crisis: Latvia. Eurohealth 2011;17(1):8-10

21 European Commission, Directorate General Health \& Consumers. Country info sheets. Health and structural funds in 2007-2013: country assessments. http://ec.europa.eu/health/ health structural funds/used for health/info sheets/index en.htm.

22 Newhouse JP, Insurance Experiment Group. Free for all? Lessons from the RAND health insurance experiment. Harvard University Press, 1993

23 Lohr KN, Brook RH, Kamberg CJ, Goldberg GA, Leibowitz A, Keesey J, et al. Effect of cost sharing on use of medically effective and less effective care. Med Care 1986;24(supp 9):S31-8.

24 Gemmill M, Thomson S, Mossialos E. What impact do prescription drug charges have on efficiency and equity? Evidence from high-income countries. Int $J$ Equity Health 2008;7:12.

25 Manning WG, Newhouse JP, Duan N, Keeler EB, Leibowitz A, Marquis MS. Health insurance and the demand for medical care: evidence from a randomized experiment. Am Econ Rev 1987;77:251-77.

26 Eurostat. Self reported unmet need for medical examination or treatment, by income quintile. 2012

epp.eurostat.ec.europa.eutgmirefreshTableAction.do?tab=table\&plugin=1\&poode=tsdph270\&language=en

27 European Monitoring Drug Centre. Joint EMCDDA and ECDC rapid risk assessment. HIV in injecting drug users in the EU/EEA, following a reported increase of cases in Greece and Romania. 2012. www.emcdda.europa.eu/attachements.cfm/att_146511_EN_emcddaecdc-2012-riskassessment.pdf.

28 Lai T, Habicht J. Decline in alcohol consumption in Estonia-combined effects of strengthened alcohol policy and economic downturn. Alcohol and Alcoholism 2011;46:200-3.

29 Gili M, Roca M, Basu S, McKee M, Stuckler D. The mental health risks of economic crisis in Spain: evidence from primary care centres, 2006 and 2010. Eur J Public Health 2012. doi:10.1093/eurpub/cks035

30 Wismar M, Maier CB, Glinos IA, Dussault G, Figueras J, eds. Health professional mobility and health systems: evidence from 17 European countries. WHO Regional Office for Europe on behalf of the European Observatory on Health Systems and Policies, 2011

31 Saar P, Habicht J. Migration and attrition: Estonia's health sector and cross-border mobility to its northern neighbour. In: Wismar M, Maier C, Glinos IA, Dussault G, Figueras J, eds. Health professional mobility and health systems: evidence from 17 European countries. WHO, European Observatory on Health Systems and Policies, 2011.

32 Padaiga Z, Pukas M, Starkiene L. Awareness, planning and retention: Lithuania's approach to managing health professional mobility. In: Wismar M, Maier C, Glinos IA, Dussault G, Figueras J, eds. Health professional mobility and health systems: evidence from 17 European countries. WHO, European Observatory on Health Systems and Policies, 2011.

33 Mladovsky P, Srivastava D, Cylus J, Karanikolos M, Evetovits T, Thomson S, et al. Health policy in the financial crisis. Eurohealth 18(1):3-6.

34 Charlemagne: Latvian lessons. The Baltics are growing after austerity-and they resent Mediterranean bail-outs. Economist June 9, 2012. www.economist.com/node/21556580.

35 McDaid D, Suhrcke M. The contribution of public health interventions: an economic perspective. In: Figueras J, McKee M, eds. Health systems, health, wealth and societal well-being assessing the case for investing in health systems. Open University Press, 2012.

36 Mladovsky P, Srivastava D, Cylus J, Karanikolos M, Evetovits T, Thomson S, et al. Health policy responses to the financial crisis in Europe. Policy summary 5 . World Health Organization, 2012. www.euro.who.int/_data/assets/pdf_file/0009/170865/e96643.pdf.

Accepted: 18 October 2012

Cite this as: BMJ 2012;345:e7348

(c) BMJ Publishing Group Ltd 2012 
This paper is part of an occasional series prepared in conjunction with the European Observatory on Health Systems and Policies (www. healthobservatory.eu)

\section{Table}

\begin{tabular}{|c|c|c|c|}
\hline & Estonia & Latvia & Lithuania \\
\hline Health budget & $\begin{array}{l}24 \% \text { cut (2009) in public health budget } \\
2 \% \text { decrease in budget of Estonian Health } \\
\text { Insurance Fund }\end{array}$ & $\begin{array}{l}89 \% \text { cut (2008-10) in public health budget } \\
13 \% \text { (2009) and } 14 \%(2010) \text { cuts in government } \\
\text { health budget }\end{array}$ & $\begin{array}{l}10 \% \text { cut }(2008-10) \text { in public health budget } \\
3 \% \text { cut }(2009) \text { in budget of National } \\
\text { Health Insurance Fund }\end{array}$ \\
\hline $\begin{array}{l}\text { Scope of benefit } \\
\text { package }\end{array}$ & $\begin{array}{l}\text { Cash benefits for dental checks for adults } \\
\text { abolished } \\
\text { Reduction in sick leave benefits }\end{array}$ & $\begin{array}{l}\text { Non-emergency hospital care excluded (2009) } \\
\text { and shifted to day care }\end{array}$ & $\begin{array}{l}\text { No cuts } \\
\text { Reduction in sick leave benefits }\end{array}$ \\
\hline $\begin{array}{l}\text { Health service prices } \\
\text { and payment } \\
\text { methods }\end{array}$ & $6 \%$ decrease in prices $(2009-10)$ & $\begin{array}{l}\text { Minimum } 10 \% \text { cut in prices } \\
\text { Switch from fee-for-service payments back to } \\
\text { global budgeting }\end{array}$ & $\begin{array}{l}\text { Decrease in reimbursements; but less so } \\
\text { for capitation for family doctors and } \\
\text { promoted services } \\
\text { Ambulance and primary healthcare } \\
\text { services are excluded }\end{array}$ \\
\hline Cost sharing & $\begin{array}{l}15 \% \text { cost sharing for inpatient nursing care } \\
\text { Primary care access kept free of charge } \\
\text { Cost sharing for other services kept at same level }\end{array}$ & $\begin{array}{l}59 \% \text { increase in cost sharing in } 2009 \text { (including } \\
\text { drugs) } \\
\text { New cost sharing for expensive diagnostics } \\
\text { Cost sharing ceiling increased }\end{array}$ & No change \\
\hline Salaries & Average $4 \%$ cut & Average $20 \%$ cut in 2009 for all health workers & No cuts \\
\hline $\begin{array}{l}\text { Care volume and } \\
\text { prioritisation }\end{array}$ & $\begin{array}{l}\text { No reduction in primary care volume } \\
5 \% \text { volume reduction of specialised care by } \\
\text { extending waiting times and reducing treatment } \\
\text { cases } \\
\text { Shifting more cases to day care and outpatient } \\
\text { settings }\end{array}$ & $\begin{array}{l}\text { No reduction in primary care volume, even more } \\
\text { financing } \\
\text { Less funding for inpatient care } \\
\text { Extended waiting times in hospital care } \\
\text { (non-emergency services) }\end{array}$ & $\begin{array}{l}\text { Additional money from reserves for } \\
\text { outpatient care } \\
\text { Less funding for inpatient care }\end{array}$ \\
\hline Public health & $\begin{array}{l}\text { Priority given to communicable diseases (eg HIV } \\
\text { and tuberculosis) at the expense of } \\
\text { non-communicable diseases (eg cardiovascular } \\
\text { disease and cancer control) } \\
\text { Use of EU structural funds (available until end of } \\
\text { 2012) to cover selected measures in the area of } \\
\text { non-communicable diseases }\end{array}$ & $\begin{array}{l}\text { Public Health Agency was closed in } 2009 \\
\text { Several public health functions were allocated to } \\
\text { the State Infectology Centre, the Centre of Health } \\
\text { Economics, and the State Health Inspection } \\
\text { Some public health functions were lost }\end{array}$ & $\begin{array}{l}\text { Restructuring the network of national } \\
\text { public health institutions } \\
\text { Implementing a network of local public } \\
\text { health bureaus }\end{array}$ \\
\hline
\end{tabular}




\section{Figures}

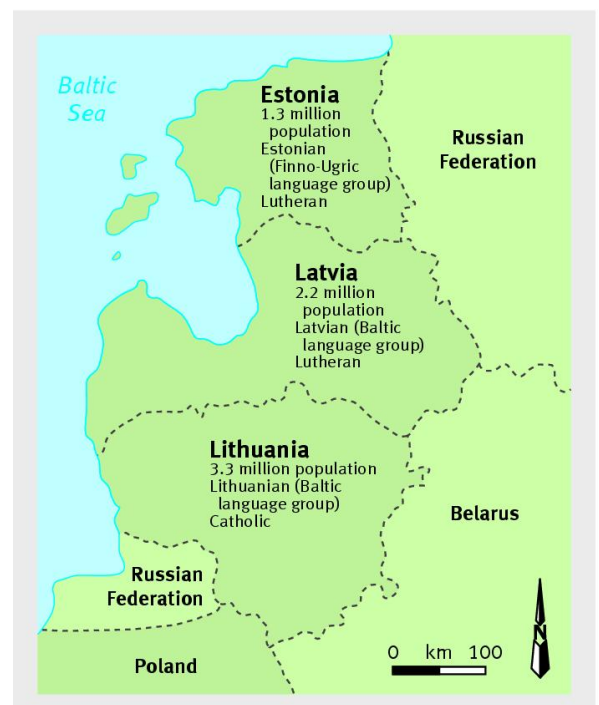

Fig 1 Often viewed as one entity, the Baltic states portray some important differences

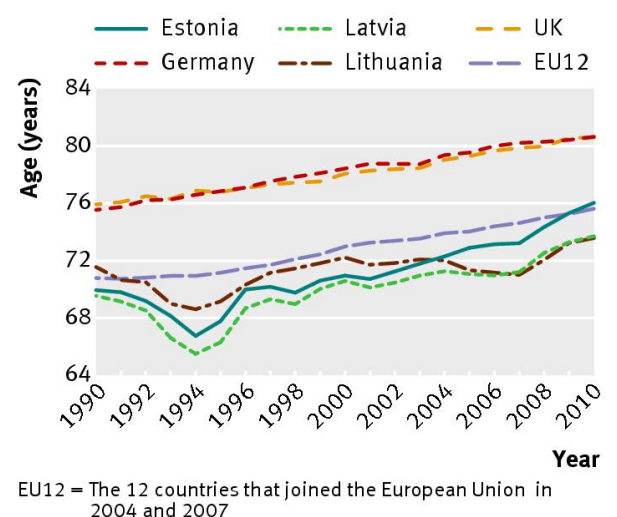

Fig 2 Life expectancy in the Baltic states, Germany, the United Kingdom, and the EU12 (1990-2010). Adapted from the World Health Organization Regional Office for Europe ${ }^{10}$

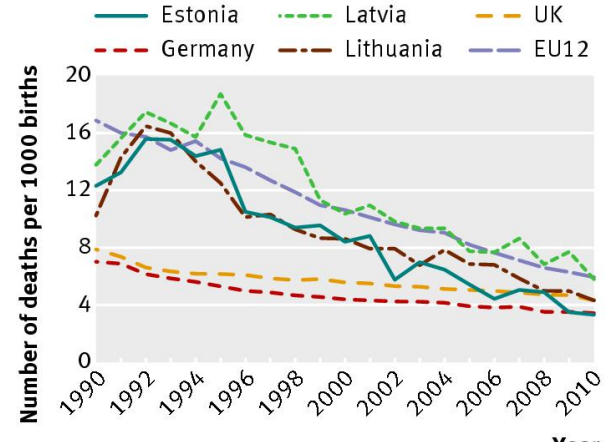

EU12 $=$ The 12 countries that joined the European Union in

Fig 3 Infant mortality in the Baltic states, Germany, the United Kingdom, and the EU12 (1990-2010). Adapted from the World Health Organization Regional Office for Europe ${ }^{10}$ 